\title{
South Asia: Clarify goals and expand the reach of anti-trafficking programs
}

Frontiers in Reproductive Health

Follow this and additional works at: https://knowledgecommons.popcouncil.org/departments_sbsr-rh

Part of the Demography, Population, and Ecology Commons, Gender and Sexuality Commons, and the Migration Studies Commons

How does access to this work benefit you? Let us know!

\section{Recommended Citation}

"South Asia: Clarify goals and expand the reach of anti-trafficking programs," FRONTIERS OR Summary. Washington, DC: Population Council, 2002. 


\section{South Asia Trafficking}

\section{OR Summary 28}

\section{Clarify Goals and Expand the Reach of Anti-Trafficking Programs}

\author{
Laws to eliminate human trafficking in South Asia should uphold interna- \\ tional covenants and human rights standards to ensure that both citizens \\ and non-citizens receive humane treatment. Programs to oppose trafficking \\ should develop clear objectives and indicators to demonstrate success and \\ point out directions for future operations.
}

\section{Background}

Each year, a significant number* of adults and children become victims of human traffickingforced transportation within or across country borders for exploitation in the form of forced sex, labor, or other services unwillingly given.

In September 2001 the Population Council collaborated with the Program for Appropriate Technology in Health (PATH), and the United Nations Development Fund for Women (UNIFEM) to conduct a consultative meeting on anti-trafficking programs in South Asia. About 50 participants from national and international human rights and anti-trafficking organizations attended the three-day meeting, held in Kathmandu, Nepal. The meeting was organized around three objectives: clarifying the definition of trafficking; describing the strengths and weaknesses of legal and programmatic approaches to combat trafficking in the region; and

\footnotetext{
*Trafficking: How Many Victims?

It is impossible to determine the exact number of trafficked persons because of the corruption and bribery surrounding the practice. However, the Congessional Research Service estimates that as many as 50,000 people are trafficked annually in Africa, 75,000 in Eastern Europe, 100,000 in Latin America and the Caribbean and the Newly Independent States, respectively, and 375,000 in Asia. ("Trafficking in Women and Children: The U.S. and International Response," CSR Report 98-659 C, May 2000)
}

identifying methods and indicators for evaluating and improving anti-trafficking interventions.

\section{Findings}

International conventions \& national laws

- Trafficking has been sufficiently defined for programs to move forward. The United Nations Protocol to Prevent, Suppress and Punish Trafficking in Persons, Especially Women and Children (December 2000), provides the internationally accepted definitions of trafficking. To date, 81 states have signed the protocol.

- Within countries in South Asia, the enforcement of the accepted definition is distorted by confounding issues such as pervasive gender biases, overly generalized laws, and abuses of legal migration. As a result, governments often fail to prevent trafficking or punish traffickers, and routinely violate the human rights of trafficking victims. Common problems with antitrafficking legislation include:

\footnotetext{
$\rightarrow$ A misplaced need to protect women, resulting in legislation which disempowers women by limiting their mobility within and across borders;

$\leftrightarrow$ Conflation of trafficking-related abuses with other types of abuses such as rape, child pornography, prostitution, and battering;
} 
$\rightarrow$ Failure to protect the rights of non-citizens; and $\leftrightarrow$ Confusion of trafficking with other types of "irregular" migration, such as illegal migration or smuggling (see Figure).

\section{Interventions against trafficking}

- Trafficking comprises a dynamic process consisting of four stages: pre-movement, movement, exploitation and post-exploitation; and interventions are specific to each stage of the process. To be effective, interventions must be context-specific and respond to the physical, emotional, educational, and social needs of vulnerable groups or rescued victims, and must address the legal prosecution of traffickers.

- Nongovernment organizations (NGOs) can play a particularly vital role as implementers of antitrafficking programs. Successful NGO programs, which typically address the social, emotional, and physiological needs of victims or potential victims, should include close coordination with programs operated by local government agencies, particularly the legal and judicial agencies, to ensure humane treatment of rescued victims.

- It is critical to find mechanisms to scale up programs so as to reach larger numbers of trafficked persons while maintaining the individualized care available from smaller programs. One way of achieving this would be the formation of NGO networks to coordinate program activities.

\section{Movement Within or Across Borders}

Consent
Illegal
Brokerage fee
Improvement of
livelihood

Trafficking

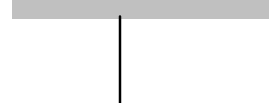

Force or coercion Deception

Debt Bondage Deliberate exploitation

Adapted from the model presented in Human Rights in Practice, Global Alliances Against Trafficking in Women, Bangkok 1999, p. 8.

\section{Policy Implications}

- Government and NGO agencies must remember that human trafficking is a manifestation of deeper problems within societies and requires long-term strategies to address those conditions that permit trafficking to flourish, including disparieties of wealth, disempowerment of women, and the absence of clear-cut immigration and migration policies.

- Anti-trafficking programs must use a combination of tools including international conventions, national legislation, community mobilization, individualized care, and coordinated reintegration services. Within South Asia, efforts to prevent trafficking must foster improvement of legislation to prosecute traffickers without constraining women's mobility or rights.

- Agencies specialized in reproductive health or HIV/AIDS should incorporate interventions for trafficked persons into their programs.

June 2002

Huntington, Dale. 2002. Anti-Trafficking Programs in South Asia: Appropriate Activities, Indicators and Evaluation Methodologies. Summary Report of a Technical Consultative Meeting. For more information, contact: Population Council, Sanga Rachana 53, Lodi Estate, $3^{\text {rd }}$ Floor, New Delhi 1100003, India. Tel./Fax: 91-11-461-0913; E-mail: frontiers@pcindia.org 